\title{
Phosphorylation of Calmodulin by Permeabilized Fibroblasts Overexpressing the Human Epidermal Growth Factor Receptor
}

\author{
Trinidad De Frutos ${ }^{a}$, José Martín-Nieto and \\ Antonio Villalobo* \\ Instituto de Investigaciones Biomédicas, \\ Consejo Superior de Investigaciones Científicas, \\ Arturo Duperier 4, E-28029 Madrid, Spain \\ • Corresponding author
}

\begin{abstract}
Detergent-permeabilized EGFR-T17 fibroblasts, which overexpress the human epidermal growth factor (EGF) receptor, phosphorylate both poly-L-(glutamic acid, tyrosine) and exogenous calmodulin in an EGF-stimulated manner. Phosphorylation of calmodulin requires the presence of cationic polypeptides, such as poly-L(lysine) or histones, which exert a biphasic effect toward calmodulin phosphorylation. Optimum cationic polypeptide/calmodulin molar ratios of 0.3 and 7 were determined for poly-L-(lysine) and histones, respectively. Maximum levels of calmodulin phosphorylation were attained in the absence of free calcium, and a strong inhibition of this process was observed at very low concentrations $(K \mathrm{i}=0.2 \mu \mathrm{M})$ of this cation. The incorporation of phosphate into calmodulin occurred predominantly on tyrosine residue(s) and was stimulated 34-fold by EGF.

Key words: Cell permeabilization / Phosphocalmodulin / Tyrosine kinase.
\end{abstract}

\section{Introduction}

The epidermal growth factor receptor (EGFR) is an integral membrane tyrosine kinase glycoprotein of $170 \mathrm{kDa}$ involved in cell proliferation and differentiation processes in a variety of cell types. Signalling by this receptor involves its transphosphorylation and the phosphorylation of intracellular target proteins, which commits the cell to its mitotic division (Carpenter, 1987; Schlessinger, 1988; Ullrich and Schlessinger, 1990; Fantl et al., 1993). Additionally, one of the early events occurring during the transduction of the mitogenic signal mediated by the EGFR is an increase in the cytosolic concentration of free $\mathrm{Ca}^{2+}$ (Moolenaar et al., 1986; Pandiella et al. , 1988).

\footnotetext{
a Present address: Laboratorio de Nefrología e Hipertensión, Fundación Jiménez Diaz, Avda. Reyes Católicos 2, E-28040 Madrid, Spain.
}

A number of $\mathrm{Ca}^{2+}$-dependent enzymes and cellular processes have been shown to be modulated by the intracellular $\mathrm{Ca}^{2+}$ receptor protein, calmodulin (Means and Dedman, 1980; Klee and Vanaman, 1982; Bachs et al., 1992; James et al., 1995), including the regulation of cell division (Neigl et al., 1984; Reddy et al., 1994; Bachs et al., 1994; Takuwa et al., 1995). Additional experimental evidence obtained in our laboratory supports the involvement of calmodulin in the regulation of cell proliferation (San José et al., 1992; Benguria and Villalobo, 1993; Benguria et al., 1994, 1995a). First, the EGFR is isolated from solubilized rat liver plasma membranes by $\mathrm{Ca}^{2+}$-dependent calmodulin-affinity chromatography. Second, the isolated receptor phosphorylates exogenous calmodulin on tyrosine- 99 with a stoichiometry close to 1 , in the absence of $\mathrm{Ca}^{2+}$ and presence of a cationic polypeptide as cofactor. Third, calmodulin inhibits both the EGFR transphosphorylation and EGFR-mediated phosphorylation of exogenous substrates in a $\mathrm{Ca}^{2+}$-dependent manner. Taken together, these results led us to postulate that calmodulin exerts a regulatory role on the EGFR tyrosine kinase activity (San José et al., 1992; Benguria and Villalobo, 1993; Benguria et al., 1994; 1995a).

In this work we demonstrate that exogenous calmodulin is phosphorylated in vitro in an EGF-stimulated manner by permeabilized fibroblasts overexpressing the EGFR. This phosphorylation process exhibits similar properties to those determined for the isolated EGFR from rat liver (San José et al., 1992; Benguria and Villalobo, 1993; Benguria et al., 1994, 1995a), which suggests that EGFmediated phosporylation of calmodulin may be a generalized process among mammalian cells.

\section{Results and Discussion}

\section{Assay of the Epidermal Growth Factor Receptor Tyrosine Kinase Activity in Permeabilized Cells}

The EGFR-T17 fibroblast cell line is an NIH 3T3-derived clone which has been stably transfected with a human EGFR cDNA using a retroviral expression system (Velu et al., 1987; Pandiella et al., 1988). These cells overexpress high affinity $\left(K_{d}=3-5 \mathrm{nM}\right)$ human EGFR, at a number of $4 \times 10^{5}$ receptors/cell as estimated by $\left[{ }^{125}\right.$ ] EGF binding assays, and develop a transformed phenotype in the presence of EGF in the culture medium (Velu et al., 1987; Pandiella et al., 1988), thus constituting a valuable material for the study of signalling processes mediated by the EGFR (Pandiella et al., 1988, 1989; Magni et al., 1991). 
To test whether the EGFR-T17 fibroblasts would constitute a suitable material for the assay of EGFR tyrosine kinase activity, we performed in vitro phosphorylation assays in which the cells were permeabilized with $0.1 \%(\mathrm{w} / \mathrm{v})$ Triton $\mathrm{X}-100$ prior to the addition of $\left[\gamma^{-32} \mathrm{P}\right]$ ATP. This treatment preserved the boundary and the gross organization of the cell, as assessed by phase-contrast light microscopy (results not shown). Using this assay system we have found that the addition of $1 \mu \mathrm{M}$ EGF resulted in a $4.3 \pm 0.8$ (mean \pm S.E.M., $n=7$ )-fold increase in the phosphorylation of a $170 \mathrm{kDa}$ band, as shown in Figure 1 (lanes 1 and 2). The identity of this band as the phosphorylated EGFR was confirmed through covalent cross-linkage of $\left.\left[{ }^{125}\right]\right] E G F$ to the $170 \mathrm{kDa}$ protein in whole non-permeabilized cells (results not shown). Furthermore, we have previously shown that the $170 \mathrm{kDa}$ phosphoprotein is immunoprecipitated from EGFR-T17 cell lysates using a highly-specific anti-EGFR polyclonal antibody (Elexpuru et al., 1994). The permeabilized cell system was also suitable for the assay of the EGF-dependent phosphorylation of exogenous substrates. As also shown in Figure 1 (lanes

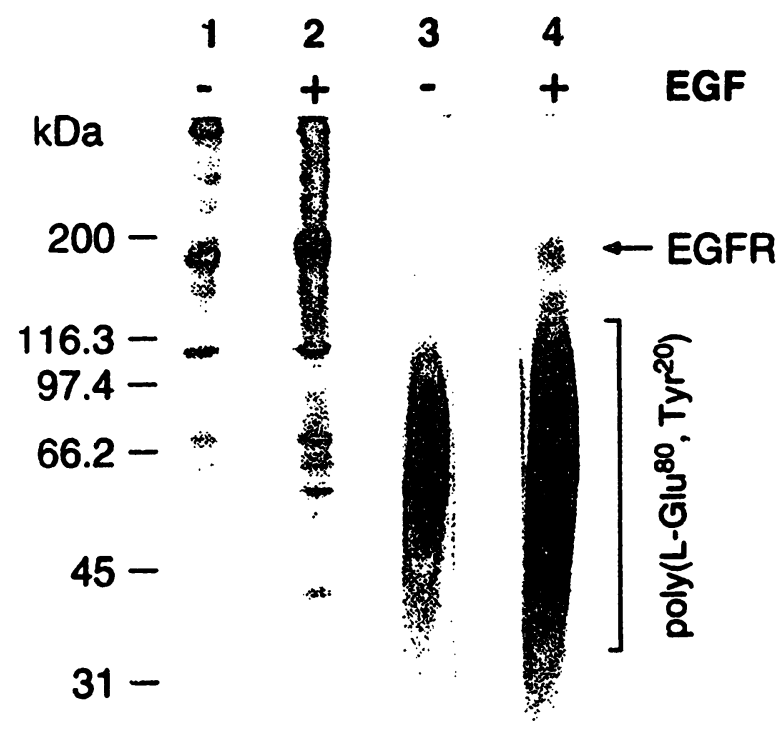

$21.5-$

$14.4-$

Fig.1 Tyrosine Kinase Activity in Permeabilized EGFR-T17 Fibroblasts.

Permeabilized EGFR-T17 fibroblasts $\left(2-2.5 \times 10^{4}\right.$ cells) were incubated for $30 \mathrm{~min}$ at $0^{\circ} \mathrm{C}$ in the absence (lanes 1 and 3 ) and presence (lanes 2 and 4) of $1 \mu \mathrm{MEGF}$, and phosphorylation was carried out at $37^{\circ} \mathrm{C}$ for $3 \mathrm{~min}$ in the absence (lanes 1 and 2) and for $1.5 \mathrm{~min}$ in the presence (lanes 3 and 4 ) of $100 \mu \mathrm{g} / \mathrm{ml}$ poly-L-(Glu, Tyr) as described in Materials and Methods. The reaction was stopped by addition of ice-cold $10 \%(w / v)$ trichloroacetic acid, and the precipitated proteins were processed by SDS-PAGE and autoradiography. The arrow points to the phosphorylated EGFR in the autoradiograph, and the bracket denotes the smear corresponding to phosphorylated poly-L-(Glu, Tyr).
3 and 4), the phosphorylation of the artificial substrate poly-L-(Glu, Tyr), migrating in the gels as a broad smear along the lanes, was markedly enhanced by the presence of EGF.

When the phosphorylation of the EGFR was assayed in the presence of different concentrations of the ligand, we obtained a half-maximal stimulation of this process at $5 \mathrm{~nm}$ EGF (results not shown). Phosphoamino acid analysis of the EGFR revealed that serine, threonine and tyrosine residues were phosphorylated to similar extents in the $a b$ sence of EGF. Upon addition of this growth factor, however, the phosphorylation of serine and threonine residues was not significantly enhanced, whereas the phosphorylation of tyrosine residues increased by over 3-fold (results not shown).

\section{Phosphorylation of Calmodulin by Permeabilized Cells}

Since our assay system allowed the detection of EGF-dependent phosphorylation of exogenous substrates, and since the EGFR isolated from rat liver plasma membranes had been shown to phosphorylate exogenously added calmodulin (San José et al., 1992; Benguria and Villalobo, 1993; Benguria et al., 1994, 1995a), we tested whether EGF-dependent phosphorylation of calmodulin also occurred in permeabilized EGFR-T17 fibroblasts.

The phosphorylation of calmodulin by the rat liver EGFR had been previously shown to require the presence of a cationic polypeptide, such as poly-L-(lysine) or histones (San José et al., 1992; Benguria and Villalobo, 1993; Benguria et al., 1994, 1995a). Therefore, we assayed calmodulin phosphorylation by permeabilized fibroblasts in the absence and presence of these cationic polypeptides. Calmodulin was not phosphorylated in the absence of these cofactors, either in the absence or presence of EGF, whereas phosphorylated calmodulin was readily detected by including poly-L-(lysine) or histones (types $\mathrm{H} 2, \mathrm{H} 3$ and $\mathrm{H} 4$ ) in the assays (see Figure 2). Phosphocalmodulin displayed the $\mathrm{Ca}^{2+}$-dependent electrophoretic mobility shift characteristic of non-phosphorylated calmodulin (Burgess et al., 1980), migrating as a double band at $16.5 \mathrm{kDa}$ (major component) in the presence of $\mathrm{Ca}^{2+}$ (not shown) and as a single band at $21 \mathrm{kDa}$ in the presence of EGTA (Figure 2). Phosphorylation of calmodulin was stimulated $1.7 \pm 0.5$-fold (mean \pm S.E.M., $n=3$ ) and $2.6 \pm$ 0.2 -fold (mean \pm S.E.M., $n=4$ ) by EGF in the presence of poly-L-(lysine) and histones, respectively. In addition, the phosphorylation of a number of cellular proteins was also enhanced by these cationic polypeptides, as previously reported (Gatica et al. , 1987).

Optimal phosphorylation of calmodulin by distinct protein kinases, including casein kinase II (Meggio et al., 1987; Sacks and McDonald, 1992), spleen tyrosine protein kinase III (Meggio et al., 1987), the insulin receptor (Laurino et al., 1988; Sacks and McDonald, 1988; Sackset al., 1989) and the EGFR from rat liver (San José et al. , 1992; Benguria et al., 1994), has been reported to occur within 


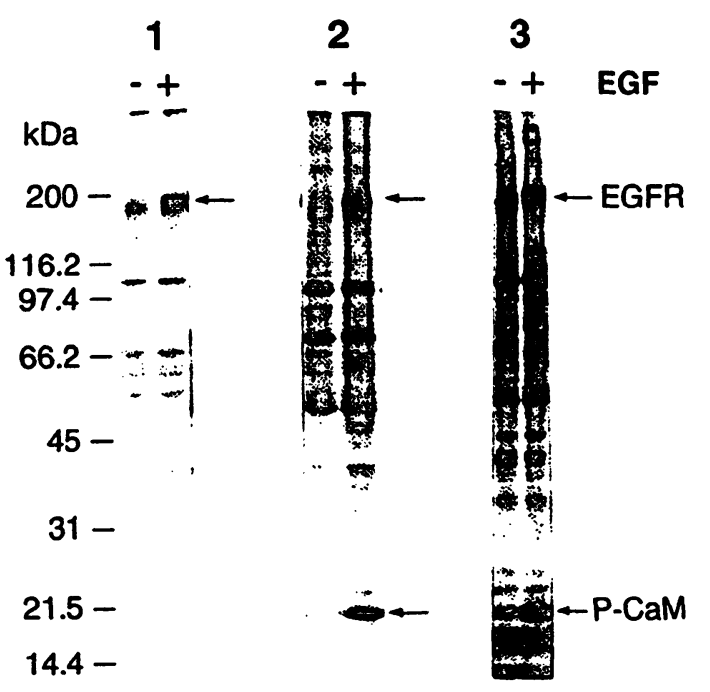

Fig. 2 Phosphorylation of Calmodulin Requires a Cationic Polypeptide.

Permeabilized EGFR-T17 fibroblasts $\left(2-2.5 \times 10^{4}\right.$ cells) were incubated for $30 \mathrm{~min}$ at $0^{\circ} \mathrm{C}$ in the absence $(-)$ and presence $(+)$ of $1 \mu \mathrm{MEGF}$. Thereafter, $1 \mu \mathrm{M}$ calmodulin was added and phosphorylation assays were carried out at $37^{\circ} \mathrm{C}$ for $3 \mathrm{~min}$ in the absence (lanes 1) and presence of either $0.3 \mu \mathrm{M}$ poly-L-(lysine) (lanes 2) or $5 \mu \mathrm{M}$ histones (lanes 3 ) as described in Materials and Methods. After stopping the reaction with ice-cold $10 \%(\mathrm{w} / \mathrm{v})$ trichloroacetic acid, the precipitated proteins were dissolved in sample buffer containing $10 \mathrm{~mm}$ EGTA and analyzed by SDSPAGE and autoradiography. Arrows point to the phosphorylated EGFR and to phosphorylated calmodulin (P-CaM).

narrow ranges of cationic polypeptide/calmodulin molar ratios. Above and below the optimal concentrations of cationic polypeptide, calmodulin phosphorylation was drastically reduced or undetected. In order to determine whether this effect also occurred for the human EGFR in the permeabilized-cell system, the EGF-dependent phosphorylation of calmodulin was analyzed by including different concentrations of either poly-L-(lysine) or histones while keeping constant the concentration of calmodulin.

As illustrated in Figure 3, a biphasic effect of both types of cationic polypeptides toward calmodulin phosphorylation was observed both in the absence and presence of EGF. From these experiments we calculated optimal molar ratios of approximately 0.3 for poly-L-(lysine)/calmodulin (Figure $3 \mathrm{~A}$ ) and 7 for histone/calmodulin (Figure $3 \mathrm{~B}$ ), both in the absence and presence of the ligand. These values agree well with those we have previously reported for the isolated EGFR from rat liver, of 0.2 for the poly-L(lysine)/calmodulin molar ratio and of 3-9 for the histone/calmodulin molar ratio (Benguria et al., 1994). The one-order of magnitude lower optimal molar ratio found using poly-L-(lysine) as compared to histones is most likely attributable to the higher number of positive charges present in the former cationic polypeptide (Benguria et al., 1994).

Cationic polypeptides are known to interact with a variety of protein kinases, including the insulin receptor and the EGF receptor, and to modify their catalytic and binding properties toward their substrates and ligands (Gatica et al., 1987; Fujita-Yamaguchi et al., 1989; Biener and Zick, 1991; Hubler et al., 1992, and references therein). Thus, it is possible that an alteration of the aggregation state of the EGFR promoted by these polypeptides could enhance its ability to phosphorylate calmodulin. Alternatively or additionally, cationic polypeptides could promote a conformational change in calmodulin facilitating its binding to these protein kinases and hence its phosphorylation, thereby mimicking the action of naturally-occurring cationic proteins (Fujita-Yamaguchi et al., 1989). In contrast, the addition of exogenous cationic polypeptides was not required for either the phosphorylation of endogenous calmodulin in vivo (Plancke and Lazarides, 1983; Fukami et al., 1985; Nakajo et al., 1986; Sacks et al., 1992; Joyal and Sacks, 1994) or the phosphorylation of membrane-bound calm-

A

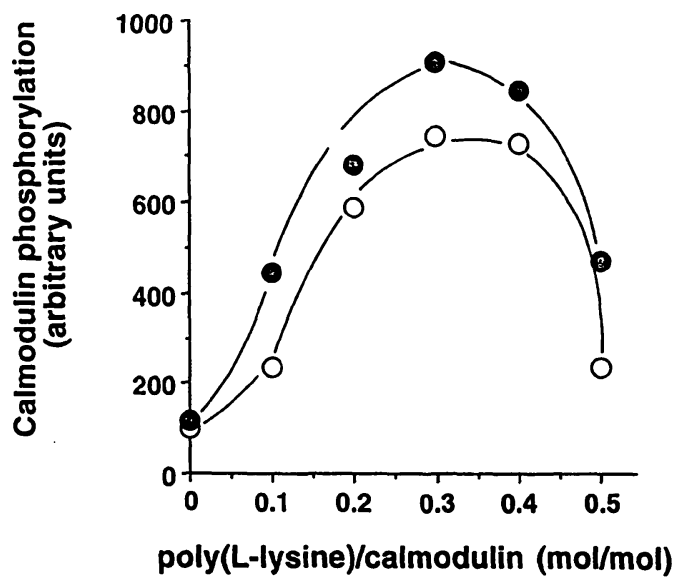

B

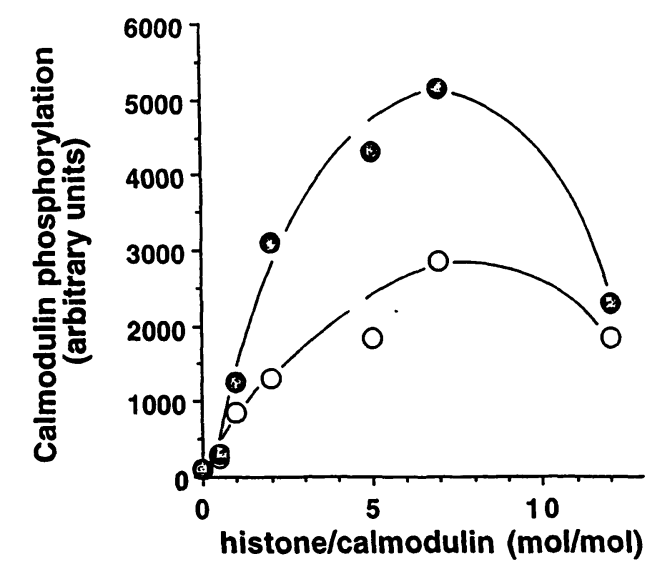

Fig.3 Biphasic Effect of Poly-L-(lysine) and Histones on Calmodulin Phosphorylation.

Phosphorylation of calmodulin was assayed as described in Figure 2, in the absence (open symbols) and presence (filled symbols) of $1 \mu \mathrm{M}$ EGF, except that different concentrations of poly-L(lysine) (panel A) or histones (panel B) were used in the assays to attain the indicated molar ratios. Phosphocalmodulin was measured densitometrically from the corresponding autoradiographs, and plotted versus the cationic polypeptide/calmodulin molar ratio. The phosphorylation of calmodulin in the absence of both EGF and cationic polypeptide was taken as 100 units. 
odulin in vitro (Benguría et al., 1995b), which suggests the existence of endogenous, positively-charged factor(s) that facilitate(s) calmodulin phosphorylation within the cell.

Calcium ions have been shown to negatively modulate the phosphorylation of calmodulin by all protein kinases studied so far, including casein kinase II (Meggio et al., 1987), spleen tyrosine protein kinase III (Meggio et al., 1987), rat liver and human placenta insulin receptors (Sacks and McDonald, 1988; Sacks et al., 1989), rat liver plasma membrane-bound kinase(s) (Benguria et al., 1995b) and the rat liver EGFR (San Jose et al., 1992; Benguria and Villalobo, 1993; Benguria et al., 1994, 1995a). In order to analyze the effect of free $\mathrm{Ca}^{2+}$ on calmodulin phosphorylation by the human EGFR expressed in EGFR-T17 fibroblasts, assays were carried out in the presence of varying concentrations of $\mathrm{CaCl}_{2}$ to yield different concentrations of free $\mathrm{Ca}^{2+}$, both in the absence and presence of EGF. As illustrated in Figure 4, maximum levels of calmodulin phosphorylation were attained in the presence of EGF and absence of $\mathrm{Ca}^{2+}$. The phosphorylation of calmodulin was progressively inhibited by increasing the concentration of free $\mathrm{Ca}^{2+}$, and this inhibition was very significant at $1 \mu \mathrm{M}$ free $\mathrm{Ca} 2+$, as was also the case for the isolated rat liver EGFR (Benguria et al., 1994). From these experiments, an apparent inhibition constant $(K i)$ of approximately $0.2 \mu \mathrm{M}$ free $\mathrm{Ca}^{2+}$ was determined for the human EGFR, both in the absence and presence of EGF.

The inhibitory effect of $\mathrm{Ca}^{2+}$ has been shown not to be attributable to inhibition of the EGFR tyrosine kinase ac-

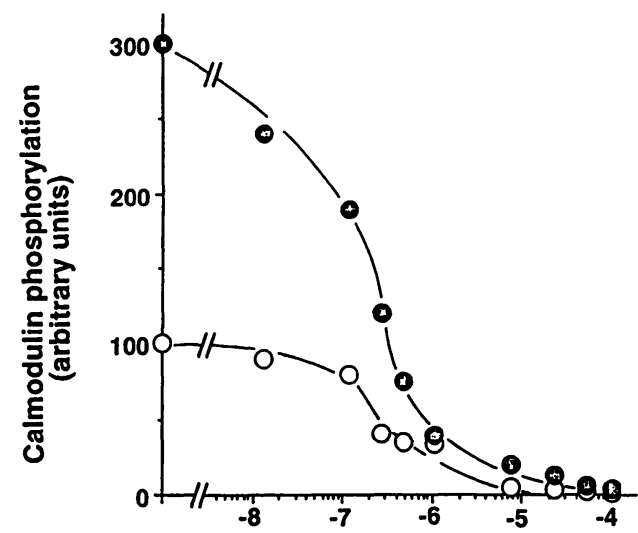

$\log \left(\left[\mathrm{Ca}^{2+}\right]_{\text {tree }} / \mathrm{M}\right)$

Fig. 4 Effect of Free $\mathrm{Ca}^{2+}$ on Calmodulin Phosphorylation.

Permeabilized EGFR-T17 fibroblasts $\left(2-2.5 \times 10^{4}\right.$ cells) were incubated for $30 \mathrm{~min}$ at $0^{\circ} \mathrm{C}$ in the absence (open symbols) and presence (filled symbols) of $1 \mu \mathrm{M}$ EGF. Thereafter, $1 \mu \mathrm{M}$ calmodulin was added and phosphorylation assays were carried out at $37^{\circ} \mathrm{C}$ for $3 \mathrm{~min}$ in the presence of $5 \mu \mathrm{M}$ histone, $0.5 \mathrm{~mm}$ EGTA and different concentrations of $\mathrm{CaCl}_{2}$ to attain the indicated concentrations of free $\mathrm{Ca}^{2+}$, as described in Materials and Methods. Phosphocalmodulin levels were measured densitometrically from the corresponding autoradiograph, and plotted versus the logarithm of the concentration of free $\mathrm{Ca}^{2+}$. The phosphorylation level obtained in the absence of both $\mathrm{EGF}$ and $\mathrm{CaCl}_{2}$ was taken as 100 units. tivity, but instead it appears to be due to a $\mathrm{Ca}^{2+}$-promoted change on the conformation of calmodulin preventing its binding to the receptor and/or rendering inaccessible the phosphorylatable residue(s) (Benguria et al., 1994). This contention is supported by the fact that the residue tyrosine-99, which is phosphorylated by the EGFR, is located in the third $\mathrm{Ca}^{2+}$-binding site of calmodulin (Benguria et al., 1994). Furthermore, the low concentration of free $\mathrm{Ca}^{2+}$ required to inhibit the EGFR tyrosine kinase activity suggests a physiological relevance for this modulatory process.

It has been reported using a membrane preparation from $A 431$ human epidermoid carcinoma cells, which also overexpress the EGFR, that EGF stimulates the phosphorylation of calmodulin solely on serine residues, indicating that this phosphorylation was not directly catalyzed by the EGFR (Lin et al., 1986). In order to ascertain that tyrosine was indeed phosphorylated in exogenous calmodulin using permeabilized EGFR-T17 fibroblasts, phosphoamino acid analysis of calmodulin was carried out after its phosphorylation in the absence and presence of EGF.

As illustrated in Figure 5A, EGF stimulated the phosphorylation of tyrosine and serine residues in the $21 \mathrm{kDa}$ calmodulin band as excised from the gel. To quantify the actual levels of phosphoamino acids in calmodulin, control experiments without exogenous calmodulin were carried out in parallel in order to subtract the background levels of phosphoamino acids from other polypeptides possibly comigrating with calmodulin in the gels. After this correction, and as shown in Figure 5B, EGF was found to promote an increase in the phosphorylation of tyrosine residue(s) of calmodulin of approximately 34 -fold, whereas serine and threonine phosphorylation increased only by 1.5- to 2-fold each as compared to the phosphorylation levels obtained in the absence of EGF. The increase in the phosphorylation of serine and threonine residues of calmodulin was due to EGF-mediated activation of serine/threonine-protein kinases.

Summarizing, permeabilized EGFR-T17 fibroblasts constitute a simple in vitro system to assay the EGFR tyrosine kinase activity, including both receptor transphosphorylation and phosphorylation of exogenous substrates, which avoids the need of using purified or immunoprecipitated EGFR preparations. Using this system, we have demonstrated that this receptor phoshorylates exogenous calmodulin and that this process exhibits properties similar to those reported by us for the EGFR isolated from rat liver. This suggests that EGF-stimulated phosphorylation of calmodulin could be a widespread phenomenon occurring in different cell types. The results reported in this work further support the contention that regulatory interactions probably exist between calmodulin and the EGFR (San José et al., 1992; Benguría and Villalobo, 1993; Benguria et al., 1994, 1995a). In addition to a possible role of calmodulin in the long-term desensitization of the EGFR that takes place upon extended exposure to its ligand (Cunningham et al., 1989; 
A

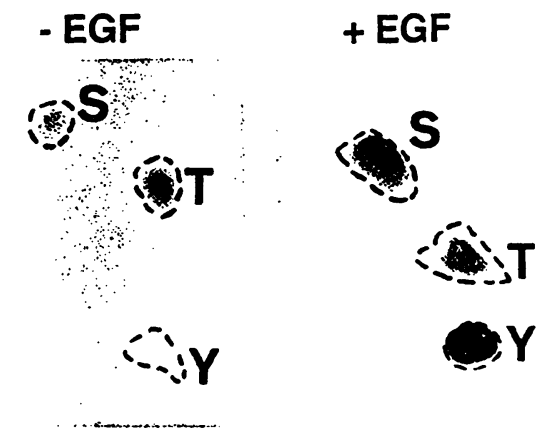

B

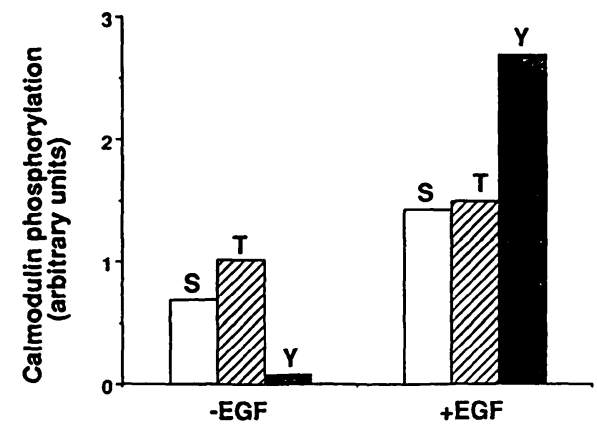

Fig. 5 Phosphoamino Acid Analysis of Phosphocalmodulin. (A) Permeabilized EGFR-T17 fibroblasts $\left(4-5 \times 10^{4}\right.$ cells) were incubated for $30 \mathrm{~min}$ at $0^{\circ} \mathrm{C}$ in the absence and presence of $1 \mu \mathrm{M}$ EGF, as indicated. Thereafter, $1 \mu \mathrm{M}$ calmodulin was added and phosphorylation assays were carried out at $37^{\circ} \mathrm{C}$ for $3 \mathrm{~min}$ in the presence of $5 \mu \mathrm{M}$ histones using $10 \mu \mathrm{M}(20 \mu \mathrm{Ci})\left[\gamma^{32} \mathrm{P}\right]$ ATP. After SDS-PAGE and autoradiography, the $21 \mathrm{kDa}$ calmodulin band was excised from the dried unstained gel and phosphoamino acid analysis was performed as indicated in Materials and Methods. The positions of migration of standard phosphoserine $(S)$, phosphothreonine $(T)$ and phosphotyrosine $(M)$ stained with ninhydrin are indicated on the autoradiographs by dashed lines. (B) Graphical representation of the relative densitometric levels of the three phosphoamino acids of calmodulin phosphorylated in the absence and presence of EGF, as indicated, after subtracting the background phosphorylation levels obtained in control assays performed in the absence of added calmodulin.

Kuppuswamy and Pike, 1989; Countaway et al., 1992), calmodulin is likely to exert a short-term inhibitory role on the tyrosine kinase activity of this receptor (San José et al., 1992; Benguria and Villalobo, 1993; Benguria et al., 1994, 1995a). Both inhibitory effects of calmodulin could prevent a continued stimulation of cell proliferation by EGF. In addition, preliminary results from our laboratory suggest that calmodulin phosphorylated by the EGFR could up-regulate its tyrosine kinase activity in vitro (Benguria and Villalobo, 1993; Benguria et al., 1995a). Therefore, the balance between phosphorylated and non-phosphorylated calmodulin is likely to modulate the intrinsic catalytic activity of the EGFR in response to transient changes in the concentration of cytosolic free $\mathrm{Ca}^{2+}$ occurring during the EGF-induced mitogenic response. Future work should elucidate whether EGF-dependent phosphorylation of calmodulin takes place in intact cells.

\section{Materials and Methods}

\section{Chemicals}

Culture medium and FCS were purchased from Gibco-BRL. [ $\gamma$ ${ }^{32}$ PJATP (triethylammonium salt) $(3000 \mathrm{Ci} / \mathrm{mmol})$ and HyperfilmMP X-ray films were obtained from Amersham. Calmodulin (from bovine brain) was purchased from Calbiochem. Receptor-grade EGF (from mouse submaxillary glands), poly-L-(Glu, Tyr) (44.5$45.7 \mathrm{kDa}$ ), poly-L-(lysine) (38 kDa), calf thymus histones (type IIAS, fraction containing histones $\mathrm{H} 2, \mathrm{H} 3$ and $\mathrm{H} 4$ as observed in SDS-PAGE), ATP (sodium salt), PMSF, EGTA, leupeptin (hemisulphate), Triton X-100, TPCK-treated trypsin, phosphoserine, phosphothreonine and phosphotyrosine were products of Sigma. Hepes, SDS, ninhydrin and thin-layer $(0.1 \mathrm{~mm})$ cellulosecoated chromatographic plates were from Merck. Molecular mass standards for electrophoresis were purchased from BioRad. Other chemicals used in this work were of analytical grade.

\section{Cell Permeabilization and Phosphorylation Assays}

Cells grown to confluency in $25 \mathrm{~cm}^{2}$ flasks with Dulbecco's modified Eagle's medium containing $10 \%$ ( $v / v) F C S, 2$ mM L-glutamine and $40 \mu \mathrm{g} / \mathrm{ml}$ gentamicin were washed with TD-buffer $(137 \mathrm{~mm}$ $\mathrm{NaCl}, 5 \mathrm{mM} \mathrm{KCl}, 1 \mathrm{~mm} \mathrm{NaH}{ }_{2} \mathrm{PO}_{4}, 20 \mathrm{~mm}$ Tris/ $\mathrm{HCl}, \mathrm{pH} 7.4$ ) and transferred to medium without FCS. After overnight incubation, the cells were washed and scraped into TD-buffer, harvested by low-speed centrifugation and resuspended in $150 \mu$ l of TD-buffer per flask. Thereafter, $50 \mu \mathrm{l}$ of a medium containing $60 \mathrm{~mm} \mathrm{Na-}$ Hepes (pH 7.4), $24 \mathrm{~mm} \mathrm{MgCl} 2,2$ mM EGTA, $0.4 \%$ (w/v) Triton X$100,0.8 \mathrm{mM} \mathrm{Na}_{3} \mathrm{VO}_{4}, 4 \mathrm{~mm}$ PMSF and $40 \mu$ m leupeptin was added. The cell suspension was incubated in this medium for $15 \mathrm{~min}$ at $0^{\circ} \mathrm{C}$ and used for phosphorylation assays.

Standard phosphorylation assays were carried out for 1 to 3 min at $37^{\circ} \mathrm{C}$ in $100 \mu$ l of a mixture containing $10 \mu$ l of the cell suspension (2-2.5 $\times 10^{4}$ permeabilized cells), $15 \mathrm{~mm} \mathrm{Na-Hepes}(\mathrm{pH}$ 7.4), $6 \mathrm{~mm} \mathrm{MgCl} 2,0.5 \mathrm{~mm}$ EGTA, $0.1 \%$ (w/v) Triton X-100, $0.2 \mathrm{~mm}$ $\mathrm{Na}_{3} \mathrm{VO}_{4}, 1 \mathrm{~mm}$ PMSF and $10 \mu \mathrm{m}$ leupeptin. Where indicated, 100 $\mu \mathrm{g} / \mathrm{ml}$ poly-L-(Glu, Tyr), $1 \mu \mathrm{M}$ calmodulin, $0.3 \mu \mathrm{M}$ poly-L-(lysine) or $5 \mu \mathrm{M}$ histones were added. The reaction was started upon addition of $10 \mu \mathrm{M}(2-3 \mu \mathrm{Ci})\left[\gamma^{-32} \mathrm{P}\right]$ ATP and stopped by addition of icecold $10 \%(\mathrm{w} / \mathrm{v})$ trichloroacetic acid. The precipitated proteins were separated by centrifugation, the supernatants discarded and the pellets processed for electrophoresis and autoradiography as indicated below.

\section{Other Analytical Procedures}

Slab-gel electrophoresis was performed according to Laemmli (1970) at $7.5 \mathrm{~mA}$ overnight at room temperature in linear $5 \%$ to $20 \%(\mathrm{w} / \mathrm{v})$ polyacrylamide gradient gels in the presence of $0.1 \%$ $(w / v)$ SDS at $\mathrm{pH}$ 8.3. When calmodulin was present in the samples, $10 \mathrm{~mm}$ EGTA was included in the electrophoresis sample buffer to obtain migration of calmodulin as a single $21 \mathrm{kDa}$ band. The gels were stained with Coomassie Brilliant Blue R-250 and dried under vacuum at $70^{\circ} \mathrm{C}$ on Whatman $3 \mathrm{MM} \mathrm{Chr}$ paper. Phosphoamino acid analysis was carried out as described (Hunter and Sefton, 1980). Briefly, the phosphorylated bands were excised from unstained dried gels and sequentially treated with $150 \mu \mathrm{g}$ TPCK-treated trypsin for $15 \mathrm{~h}$ at room temperature and $6 \mathrm{M} \mathrm{HCl}$ for $2 \mathrm{~h}$ at $110^{\circ} \mathrm{C}$, followed by two-dimensional electrophoresis on cellulose-coated plates. $X$-ray films were exposed at $-20^{\circ} \mathrm{C}$ to obtain autoradiographs. The intensity of the radiolabeled protein bands and phosphoamino acid spots were quantified by scanning the autoradiographs in a photodensitometer. The densitometric intensities of the bands were directly proportional to the amounts of ${ }^{32} \mathrm{P}$ they contained within the exposure 
times used. The concentration of free $\mathrm{Ca}^{2+}$ in the reaction mixtures was calculated by using a computer program similar to that described by Goldstein (1979).

\section{Acknowledgements}

We are indebted to the group of Dr. J.M. Mato for making the EGFR-T17 cell line available to us. This work was supported by research grants to A.V. from the Comision Interministerial de Ciencia y Tecnología (SAF93/392 and SAF96/35) and from the Dirección General de Investigación Científica y Técnica (PR94/343). J.M.-N. is the recipient of a postdoctoral research contract from the Ministerio de Educación y Ciencia.

\section{References}

Bachs, O., Agell, N., and Carafoli, E. (1992). Calcium and calmodulin function in the cell nucleus. Biochim. Biophys. Acta 1113, 259-270.

Bachs, O., Agell, N., and Carafoli, E. (1994). Calcium and calmodulin-binding proteins in the nucleus. Cell Calcium 16, 289 296.

Benguria, A., and Villalobo, A. (1993). Calmodulin and the epidermal growth factor receptor. A reciprocal regulation? BioReguladores 2, 74-85.

Benguria, A., Hernández-Perera, O., Martínez-Pastor, M.T., Sacks, D.B., and Villalobo, A. (1994). Phosphorylation of calmodulin by the epidermal-growth-factor-receptor tyrosine kinase. Eur. J. Biochem. 224, 909-916.

Benguria, A., Martín-Nieto, J., Benaim, G., and Villalobo, A. (1995a). Regulatory interaction between calmodulin and the epidermal growth factor receptor. Ann. N.Y. Acad. Sci. 766, 472-476.

Benguria, A., Soriano, M., Joyal, J.L., Sacks, D.B., and Villalobo, A. (1995b). Phosphorylation of calmodulin by plasma-membrane-associated protein kinase(s). Eur. J. Biochem. 234, 5058.

Biener, Y., and Zick, Y. (1991). Polylysine increases the number of insulin binding sites in soluble insulin receptor preparations. J. Biol. Chem. 266, 17369-17375.

Burgess, W.H., Jemiolo, D.K., and Kretsinger, R.H. (1980). Interaction of calcium and calmodulin in the presence of sodium dodecyl sulfate. Biochim. Biophys. Acta 623, 257-270.

Carpenter, G. (1987). Receptors for epidermal growth factor and other polypeptide mitogens. Annu. Rev. Biochem. 56, 881914.

Countaway, J.L., Nairn, A., and Davis, R.J. (1992). Mechanism of desensitization of the epidermal growth factor receptor protein-tyrosine kinase. J. Biol. Chem. 267, 1129-1140.

Cunningham, T.W., Kuppuswamy, D., and Pike, L.J. (1989). Treatment of A-431 cells with epidermal growth factor (EGF) induces desensitization of EGF-stimulated phosphatidylinositol turnover. J. Biol. Chem. 264, 15351-15356.

Elexpuru, A., Soriano, M., and Villalobo, A. (1994). Characterization of the epidermal growth factor receptor from Ehrlich ascites tumor cells. Biol. Chem. Hoppe-Seyler 375, 293-298.

Fantl, W.J., Johnson, D.E., and Williams, L.T. (1993). Signalling by receptor tyrosine kinases. Annu. Rev. Biochem. 62, 453-481.

Fujita-Yamaguchi, Y., Kathuria, S., Xu, Q.-Y., McDonald, J.M., Nakamo, H., and Kamata, T. (1989). In vitro tyrosine phosphorylation studies on Ras proteins and calmodulin suggest that polylysine-like basic peptides or domains may be involved in interaction between insulin receptor kinase and its substrate. Proc. Natl. Acad. Sci. USA 86, 7306-7310.

Fukami, Y., Nakamura, T., Nakayama, A., and Kanehisa, T. (1985). Phosphorylation of tyrosine residues of calmodulin in Rous sarcoma virus-transformed cells. Proc. Natl. Acad. Sci. USA 83, 4190-4193.

Gatica, M., Allende, C.C., Antonelli, M., and Allende, J.E. (1987) Polylysine-containing peptides, including the carboxy-terminal segment of the human c-Ki-ras 2 protein, affect the activity of some key membrane enzymes. Proc. Natl. Acad. Sci. USA 84, 324-328.

Goldstein, D.A. (1979). Calculation of the concentrations of free cations and cation-ligand complexes in solutions containing multiple divalent cations and ligands. Biophys. J. 26, 235-242.

Hubler, L., Leventhal, P.S., and Bertics, P.J. (1992). Alteration of the kinetic properties of the epidermal growth factor receptor tyrosine kinase by basic proteins. Biochem. J. 281, 107-114.

Hunter, T., and Sefton, B.M. (1980). Transforming gene product of Rous sarcoma virus phosphorylates tyrosine. Proc. Natl. Acad. Sci. USA 77, 1311-1315.

James, P., Vorherr, T., and Carafoli, E. (1995). Calmodulin-binding domains: just two-faced or multi-faceted? Trends Biochem. Sci. 20, 38-42.

Joyal, J.L., and Sacks, D.B. (1994). Insulin-dependent phosphorylation of calmodulin in rat hepatocytes. J. Biol. Chem. 269, 30039-30048.

Klee, C.B., and Vanaman, T.C. (1982). Calmodulin. Adv. Prot. Chem. 35, 213-321.

Kuppuswamy, D., and Pike, L.J. (1989). Ligand-induced desensitization of ${ }^{125} \mathrm{I}$-epidermal growth factor internalization. J. Biol. Chem. 264, 3357-3363.

Laemmli, U.K. (1970). Cleavage of structural proteins during assembly of the head of bacteriophage T4. Nature 227,680-685.

Laurino, J.P., Colca, J.R., Pearson, J.D., Dewald, D.B., and McDonald, J.M. (1988). The in vitro phosphorylation of calmodulin by the insulin receptor tyrosine kinase. Arch. Biochem. Biophys. 265, 8-21.

Lin, P.H., Selinfreund, R., and Wharton, W. (1986). Epiderma growth factor (EGF) sensitive phosphorylation of calmodulin (CAM) in A431 cell membrane. Fed. Proc. 45, 1693.

Magni, M., Meldolesi, J., and Pandiella, A. (1991). lonic events induced by epidermal growth factor. Evidence that hyperpolarization and stimulated cation influx play a role in the stimulation of cell growth. J. Biol. Chem. 266, 6329-6335.

Means, A.R., and Dedman, J.R. (1980). Calmodulin - an intracellular calcium receptor. Nature 285, 73-77.

Meggio, F., Brunati, A.M., and Pinna, L.A. (1987). Polycation-dependent, $\mathrm{Ca}^{2+}$-antagonized phosphorylation of calmodulin by casein kinase-2 and a spleen tyrosine protein kinase. FEBS Lett. 215, 241-246.

Moolenaar, W.H., Aerts, R.J., Tertoolen, L.G.J., and de Laat, S.W. (1986). The epidermal growth factor-induced calcium signal in A431 cells. J. Biol. Chem. 261, 279-284.

Nakajo, S., Hayashi, K., Daimatsu, T., Tanaka, K., and Nakamura, Y. (1986). Phosphorylation of rat brain calmodulin in vivo and in vitro. Biochem. Int. 13,687-693.

Pandiella, A., Beguinot, L., Velu, T.J., and Meldolesi, J. (1988). Transmembrane signalling at epidermal growth factor receptors overexpressed in NIH 3T3 cells. Phosphoinositide hydrolysis, cytosolic $\mathrm{Ca}^{2+}$ increase and alkalinization correlate with epidermal-growth-factor-induced cell proliferation. Biochem. J. 254, 223-228.

Pandiella, A., Magni, M., Lovisolo, D., and Meldolesi, J. (1989). The effects of epidermal growth factor on membrane potential. Rapid hyperpolarization followed by persistent fluctuations. J. Biol. Chem. 264, 12914-12921. 
Plancke, Y.D., and Lazarides, E. (1983). Evidence for a phosphorylated form of calmodulin in chicken brain and muscle. Mol. Cell. Biol. 3, 1412-1420.

Reddy, G.P.V., Reed, W.C., Deacon, D.H., and Quesenberry, P.J. (1994). Growth factor modulated calmodulin-binding protein stimulates nuclear DNA synthesis in hemopoietic progenitor cells. Biochemistry 33, 6605-6610.

Sacks, D.B., and McDonald, J.M. (1988). Insulin-stimulated phosphorylation of calmodulin by rat liver insulin receptor preparations. J. Biol. Chem. 263, 2377-2383.

Sacks, D.B., and McDonald, J.M. (1992). Effects of cationic polypeptides on the activity, substrate interaction, and autophosphorylation of casein kinase II: A study with calmodulin. Arch. Biochem. Biophys. 299, 275-280.

Sacks, D.B., Fujita-Yamaguchi, Y., Gale, R.O., and McDonald, J.M. (1989). Tyrosine-specific phosphorylation of calmodulin by the insulin receptor kinase purified from human placenta. Biochem. J. 263, 803-812.

Sacks, D.B., Davis, H.W., Crimmins, D.L., and McDonald, J.M. (1992). Insulin-stimulated phosphorylation of calmodulin. Biochem. J. 286, 211-216.
San José, E., Benguria, A., Geller, P., and Villalobo, A. (1992). Calmodulin inhibits the epidermal growth factor receptor tyrosine kinase. J. Biol. Chem. 267, 15237-15245.

Schlessinger, J. (1988). Signal transduction by allosteric receptor oligomerization. Trends Biochem. Sci. 13, 443-447.

Takuwa, N., Zhou, W., and Takuwa, Y. (1995). Calcium, calmodulin and cell cycle progression. Cell. Signal. 7, 93-104.

Ullrich, A., and Schlessinger, J. (1990). Signal transduction by receptors with tyrosine kinase activity. Cell 61, 203-212.

Veigl, M.L., Vanaman, T.C., and Sedwick, W.D. (1984). Calcium and calmodulin in cell growth and transformation. Biochim. Biophys. Acta 738, 21-48.

Velu, T.J., Beguinot, L., Vass, W.C., Willingham, M.C., Merlino, G.T., Pastan, I., and Lowy, D.R. (1987). Epidermal growth factor-dependent transformation by a human EGF receptor protooncogene. Science 238, 1408-1410.

Received August 6,1996; accepted October 14,1996 
